Article

\title{
Legitimizing Private Actors in Global Governance: From Performance to Performativity
}

\author{
Elke Krahmann \\ Department of Economics, Witten/Herdecke University, 58448 Witten, Germany; E-Mail: elke.krahmann@uni-wh.de
}

Submitted: 19 September 2016 | Accepted: 9 December 2016 | Published: 15 March 2017

\begin{abstract}
Global governance is frequently criticised because of major legitimacy deficits, including lack of public accountability and democratic control. Within this context, questions about the legitimacy of non-state governance actors, such as nongovernmental organizations, transnational corporations and private security companies, are neither an exception nor a surprise. Many actors have, therefore, turned to the measurement of performance, defined as publicly beneficial outcomes, in order to gain legitimacy. However, the rise of performance assessments as legitimizing practice is not without problems. Taking global security and health interventions as examples, this article contends that the immaterial, socially constructed and inherently contested nature of such public goods presents major obstacles for the assessment of performance in terms of observable, measurable and attributable outcomes. Performance is therefore frequently replaced by performativity, i.e. a focus on the repetitive enactment of specific forms of behaviour and capabilities, which are simply equated with the intended results. The implications for how global public goods are conceptualized and, ultimately, implemented are profound.
\end{abstract}

\section{Keywords}

global governance; legitimacy; performance; performance measurement; performativity

Issue

This article is part of the issue "Legitimization of Private and Public Regulation: Past and Present", edited by Klaus Dieter Wolf (Peace Research Institute Frankfurt, Germany), Peter Collin (Max Planck Institute for European Legal History, Germany) and Melanie Coni-Zimmer (Peace Research Institute Frankfurt, Germany).

(C) 2017 by the author; licensee Cogitatio (Lisbon, Portugal). This article is licensed under a Creative Commons Attribution 4.0 International License (CC BY).

\section{Introduction}

Critiques of a legitimacy deficit in global governance have increased in recent years. Not only governments but also non-state actors engaged in global governance have been accused of insufficient public accountability and control (e.g. Review of International Political Economy, 2011). Specifically, the delegation of global governance to private actors, such as non-governmental organizations (NGOs), transnational corporations and Private Security Companies (PSCs), has raised questions over the legitimacy of these actors and their growing roles (e.g. Lister, 2003; Østensen, 2011). Private governance actors frequently lack so-called 'input' legitimacy due to their limited accountability, transparency and public participation in organizational decision-making. Many have therefore turned to the measurement of performance, defined as publicly beneficial outcomes, to gain 'output' legitimacy. In fact, performance assessments have emerged as a key standard for legitimacy among state and non-state actors (e.g. Fowler, 1996; Martin \& Kettner, 1997; Radin, 2007).

However, the rise of performance measurement as legitimizing practice is not without problems. This article contends that the immaterial, socially constructed and inherently contested nature of some public goods, such as security, health or development, presents major obstacles for performance assessment in terms of observable, measurable and attributable outcomes. Performance is therefore frequently replaced by performativity, i.e. the repetitive enactment of specific forms of behaviour and capabilities, which are simply equated with the intended 
outcomes. The implications of this development are considerable. They affect not only the legitimacy but also the conceptualization, implementation and local experiences of global governance interventions. In contrast to other studies which have investigated the use and success of legitimization strategies (Joachim \& Schneiker, 2012; Østensen, 2011), this article focuses on the potential consequences (see also Lewis, 2015). Specifically, the following analysis seeks to understand the way in which the performative turn in performance measurement shapes how public goods are conceptualized, and accordingly implemented, in global governance.

While performance assessments are applied across a wide range of global governance actors and fields, this article looks at two examples in particular: security and health. Using the recent international intervention in Afghanistan as an illustration, it observes that private actors have become key agents of global governance. In the field of security governance, the US Department of Defense (DoD) has hired Private Security Companies to support the international peace and stability operation in the country. In the field of health governance, NGOs have received funds from the World Bank, the European Union (EU) and the United States Agency for International Development (USAID) to increase the health of the Afghan population. In both fields, governments and international organizations have employed performancebased contracting and performance measurements to legitimize the delegation of (public) service functions to non-state actors vis-à-vis the Afghan government and population, their own constituencies and donors, or national and international public opinion. They have argued that performance standards help to demonstrate effectiveness, ensure public accountability and generate legitimacy (Sondorp, Palmer, Strong, \& Wali, 2009, p. 141). This article aims to show that, despite vast differences between security and health governance, we can observe a shift from performance outcomes to performative acts in both fields-with comparable detrimental consequences for how these public goods are conceptualized and implemented.

\section{Legitimacy and Performance Measurement}

Legitimacy refers to the generalized perception or assumption that an entity or the actions of an entity are desirable, proper or appropriate within some socially constructed system of norms, values, beliefs and definitions (Suchman, 1995, p. 574). Since legitimacy is frequently contested it is better understood as a social process in which social actors use various strategies to gain, maintain and repair legitimacy (Johnson, Dowd, \& Ridgeway, 2006; Suchman, 1995). Legitimization strategies can build on a plethora of measures and resources, including status, authority, participatory institutions, norms, habit and outputs (Johnson et al., 2006; Scharpf, 1998). The theoretical differentiation between input and output legitimacy is important for understanding the popularity of performance assessments. ${ }^{1}$

Fritz Scharpf was the first to make the distinction between input legitimacy and output legitimacy with regard to public policy making. According to Scharpf (1998, p. 2), input legitimacy derives from 'government by the people' meaning that 'collectively binding decisions should originate from the authentic expression of the preferences of the constituency in question'. Output legitimacy, in contrast, results from 'government for the people', i.e. the notion that 'collectively binding decisions should serve the common interest of the constituency' (Scharpf, 1998, p. 2). Since the common interest is difficult to define output legitimacy has been frequently associated with the effectiveness and performance of policies, rules and regulations (Scharpf, 2009, p. 177).

The contemporary popularity of output legitimacy and performance measurements as key standards for global governance can be linked to two historical developments. The first development being the proliferation of transnational policy concerns and the associated functional expansion of international organizations and global governance interventions which frequently lack input legitimacy from local constituencies. It was in the context of European Union studies that Fritz Scharpf proposed his distinction between input and output legitimacy, arguing that the EU should concentrate on output legitimacy because its ability to gain input legitimacy from democratic participation in decision-making was limited by the absence of a united European identity and populace. Demands for improved legitimacy and public accountability have also affected other international organizations, such as the United Nations (UN), the International Monetary Fund, the World Bank and the World Trade Organization (Glenn, 2008; Take, 2012). Not even NGOs have been exempt from critical questions regarding the legitimacy, accountability and transparency of their governance contributions (Lister, 2003). Although some attempts have been made by international organizations to improve their input legitimacy by reforming their voting systems, the decision-making structures of many global governance actors remain biased in favour of a small number of Western member states or donors (Glenn, 2008).

The second development has been the ascent of Neoliberalism and New Public Management (NPM) as international economic and political ideologies. These ideologies have advocated the 'small state' and public outsourcing, arguing that the legitimacy of governmental and non-governmental actors can be best demonstrated by means of regular performance assessments. Jenny

\footnotetext{
${ }^{1}$ Since legitimacy is a concern in many disciplines there exists no uniform terminology. The terms 'procedural' or 'throughput' legitimacy are sometimes used instead of or as components of input legitimacy, whereas 'substantive' or 'pragmatic' legitimacy also denote output legitimacy (see e.g. Suchman, 1995, p. 579; Wallner, 2008, p. 424). Moral legitimacy which 'reflects a positive normative evaluation of the organization and its activities' (Suchman, 1995, p. 579) is sometimes separated from these forms, while other authors argue that normative assessments are inherent in definitions of input and output legitimacy.
} 
Lewis (2015) traces the politics and consequences of the emergence of performance measurements in detail. She writes, 'Since the 1970s, interest in measuring performance has increased, alongside concerns about public sector expenditure and the advent of NPM. Performance measurement is high on the agenda of governments in many nations, as they seek to demonstrate that the organisations and individuals that they fund and manage, even at one or more steps removed, are doing what they are mandated to do' (Lewis, 2015, p.1)

Over the past three decades, many national, international and non-state actors, including the US government, the World Bank and a multitude of international humanitarian organizations, have thus adopted performance-based contracting and implemented performance measurement systems to provide legitimacy for themselves and for the delegation of governance activities to private actors, such as NGOs and PSCs (Lynch-Cerullo \& Cooney, 2011; Radin, 2007; Spar \& Dail, 2002). These actors initially defined performance as the cost-efficient provision of public services (Martin \& Kettner, 1997, p. 17). However, cost-efficiency has proven difficult to assess and obtain. Since the 1990s, performance measurement has therefore focussed on outcomes as a key measure, rather than cost-efficiency. Common to these systems is the assertion that performance should be assessed in terms of publicly beneficial results, i.e. 'outcomes', and not merely the supply of services, i.e. 'outputs'. In the US, the Government Performance and Results Act (1993) was instrumental in introducing results-based performance assessment for US government agencies and contractors. Successive American governments have continued and expanded this practice, including the Government Performance and Results Modernization Act (2010) of the Obama administration. Similarly, the World Health Organization ([WHO] 2008, p. 2) states that 'performance measurement seeks to monitor, evaluate and communicate the extent to which various aspects of the health system meet their key objectives.... Health relates both to the health outcomes secured after treatment and to the broader health status of the population'.

Despite the popularity of performance measurements across a multitude of governance sectors, ranging from health, development and finance to security, the assessment of results faces many problems and pitfalls. Alan Fowler (1996, pp. 58-59) identifies five problems for results-based performance measurement. Firstly, the greater the number of actors that are interested or involved in the provision of a service, the greater the diversity of views on what is needed and how a service should be supplied. Secondly, external influences and factors distort service outcomes in such a way that results cannot be directly and exclusively attributed to the provision and provider of specific services. Thirdly, 'the time scales over which results can be seen or measured tend to increase when moving from outputs to outcomes and then to impacts' (Fowler, 1996, p. 59). Fourthly, whether a service is relevant and suitable for attaining specific results often rests on general assumptions about linear causal relationships between service inputs and outcomes which contradict the complexity of many issues (Fowler, 1996). Finally, the further one moves from tangible service outputs towards outcomes the greater the role of intangible intervening factors. In sum, the selection and definition of performance targets and indicators is neither simple nor clear.

\section{Measuring Security and Health}

The problems of performance measurement are exacerbated by the intangible, socially constructed and contested nature of the intended outcomes in many fields of global governance. How do we define and measure security, health or development? Security, for example, can be conceptualized in different ways. The most common understanding of security is as a condition involving a 'low probability of damage' (Baldwin, 1997, p. 13). Another definition of security refers to subjective perceptions of safety or the emotional state of freedom from anxiety (Rothschild, 1995, p. 61).

Each definition suggests different security outcomes and each faces distinct assessment problems. The statistical measurement of security as low probability of harm or damage is the most problematic, despite appearing to be closest to a definition of security as outcome. Probabilities can only be established over a long period, which may go beyond individual contracts. In addition, it appears unrealistic to demand that service providers achieve pre-defined probabilities of damage when many extraneous factors influence the level of security which are not under their control. For the same reason, it is difficult to attribute security outcomes to specific actors. If the frequency of harm decreases, it may be as much due to the interventions of a security provider as an attacker's change of strategy.

The definition and assessment of security in terms of popular perceptions seems to be able to overcome some of these performance assessment problems. It appears possible to measure and set specific targets for public security perceptions, which providers should achieve within the timeframe of their contracts. A government or international organization could, for instance, require that $80 \%$ of the local citizens feel safe. To attribute lower levels of anxiety to the provider citizens could also be asked whether and to what degree they believe specific security services, such as guarding and security checks at airports, are effective. The main problem with this definition and measure is that perceptions may vary independently of both security provision and probability of harm. The increased presence of security guards may contribute to feelings of insecurity, instead of alleviating them. Canvassing public opinions on security provider performance can thus lead to assessments that directly contradict those based on a definition of security as low probability of damage. 
Similar problems can be observed with regard to the definition and measurement of public health. What is health and how can it be assessed? The WHO has used two divergent conceptualizations of health which mirror those of security (Mathers, Salomon, Murray, \& Lopez, 2003; Salomon et al., 2003). One conceptualizes health as average disability adjusted life years (DALYs). Based on statistical data, DALYs define health, or rather the burden of bad health, in terms of 'the sum of the Years of Life Lost (YLL) due to premature mortality in the population and the Years Lost due to Disability (YLD) for people living with the health condition or its consequences' (Mathers et al., 2003, p. 320; WHO, 2016). The second concept defines health in terms of aggregate perceptions of personal 'states or conditions of functioning of the human body and mind', including but not necessarily limited to domains such as vision, hearing, affect, pain, sexual functioning, mobility, dexterity, cognition, digestion, skin and disfigurement, etc. (Salomon et al., 2003, pp. 303, 309). Moreover, the same problems with timeliness, attribution and measurability affect the assessment of health as an outcome of governance interventions, as seen in the case of security. This includes the questions of whether specific health services are indeed effective, whether subjective perceptions of health are supported or undermined by specific interventions and whether general improvements in health are indeed due to the provision of specific health services.

The conceptualization of security and health as activities, capabilities and interventions avoids these problems. These indicators can be immediately observed, quantitatively or qualitatively measured, and exclusively attributed to a single service provider. The literature on security, for instance, has defined security in terms of activities, such as prevention, deterrence, protection, resilience, pre-emption and avoidance (Krahmann, 2008, p. 383, 2011, pp. 368-371). Similarly, the World Bank (2002, p. 5) denotes public health as interventions designed to control and prevent disease, including 'surveillance and control of risks and damages in public health; Management of communicable and non-communicable diseases; Health promotion; Behavior change interventions for disease prevention and control; Social participation and empowerment of citizens in health; Reducing the impact of emergencies and disasters on health'.

To be sure, the definition and assessment of security and health in terms of activities, capabilities and interventions leads to clear and seemingly objective targets. Security and health interventions can easily be specified, e.g. 'carry out security patrols every hour' or 'vaccinate $80 \%$ of the population'. However, these tasks represent outputs and not outcomes. As the next section will argue, they implicitly assume causal connections between activities, capabilities and interventions and the intended outcomes which are socially constructed and vary among socio-cultural contexts. Patrols can sometimes deter threats, while at other times they only displace them in space or time. Vaccination can have unin- tended side effects or encourage populations to engage in more risky behaviour. In short, the focus on activities, capabilities and interventions replaces 'outcomes' with 'performative acts'.

\section{From Performance to Performativity}

The notion of 'performativity' and associated 'performative acts' has been developed, among others, by Judith Butler in her analysis of sex and gender. Butler $(1988,1990)$ argues that gender identities are constituted through repetitive performative acts and not biological or social conditioning. Such repetitive acts range from the daily wearing of corsets in Victorian times to mannerisms. Performative acts shape the material body of the performer so that it conforms to shared ideas of gender and influences the perceptions of the audience with regards to the performer's gender identity. Performative acts do not only create gender, they are also fundamental to the social construction and production of other concepts and entities, such as air space (Williams, 2011). Several authors have analysed how performativity underpins security (e.g. Bialasiewicz et al., 2007; Brassett \& Vaughn-Williams, 2015).

The most comprehensive application of the concept of performativity to security can be found in Higate and Henry's $(2009,2010)$ analysis of UN peacekeeping. Their research illustrates that performative acts produce security outcomes. However, whether and how performative acts influence levels of harm or subjective perceptions of security is by no means pre-determined. Higate and Henry observe two components which influence the 'success' of performative acts in creating perceptions and experiences of security. The first component is the 'choreographed drama' and theatre-like performances, based on the repetitive re-enactment of specific activities ( $\mathrm{Hi}$ gate \& Henry, 2010, p. 42). Higate and Henry (2009, p. 99) write that 'audiences express perceptions of security and insecurity as they appraise the credibility of security performance played out before them'. The persuasiveness of these performances in the eyes of clients, the public or potential attackers rests on the repetitive enactment of military expertise and prowess in the form of security practices such as drills, patrols and security checks ( $\mathrm{Hi}-$ gate \& Henry, 2009, p. 99).

The second component of security as a performative act is the presentation and use of certain capabilities as 'props' to lend persuasiveness and legitimacy to a security performance (Higate \& Henry, 2009, p. 114). In the UN peacekeeping mission in Liberia, Higate and Henry (2009, p. 114-italics in the original) observed that 'equipment was often used as the key criterion for security performance and, in turn, the creation of safe space'.

Zaiotti (2011, p. 543) adds a third condition for the productive capabilities of performative acts by arguing that cultural and historical practices influence which activities are associated with certain identities, materialities and experiences. Audiences interpret practices as 
contributing to security only if they conform to preexisting socio-cultural ideas of 'security', activities and capabilities. Performativity works within ideational and normative contexts that 'precede, constrain, and exceed the performer' (Butler, as cited in Zaiotti, 2011, p. 543).

The theory of performativity contributes in two ways to our understanding of what happens when performance measurement focusses on performative acts. Firstly, it suggests that activities, capabilities and interventions are not only selected as performance measures because they are more easily observed and attributed to service providers than the actual outcomes of these performative acts. Rather, it contends that the definition of security and health as performative acts represents a distinct conceptualization which assumes that activities, capabilities and interventions are already what they seek to achieve. As Butler (1990, p. 25) writes "There is no gender identity behind the expressions of gender; that identity is performatively constituted by the very 'expressions' that are said to be its results". According to a performative definition, deterrence and protection mean security; vaccination and consultations represent health. These definitions are not only embraced for practical reasons but also connote a different understanding of security and health as 'outcomes'. Actors who make performative definitions of security and health the basis of their performance assessments thus fail to see the contingent and socially constructed relationship between repetitive performative acts and its material and immaterial effects on security and health.

Secondly and related to the above, the observation that performative acts operate (only) within pre-existing ideas and norms about 'appropriate' security activities or health interventions suggests the possibility of a problematic disconnect between the global governance actors who define performance tasks and the local populations who are the intended beneficiaries of these interventions. The global governance administrators and providers who select specific activities, capabilities and interventions to promote security and health may have little understanding of how these will be interpreted and understood within foreign contexts with serious implications for their effectiveness and legitimacy. Importantly, this observation goes beyond the argument that security and health interventions may have unintended consequences (e.g. Fowler, 1996, p. 59). It highlights instead the socially constructed nature of performance indicators as well as the socially constructed nature of local reactions to global security and health interventions. The next two sections illustrate the move from performance to performativity in the cases of private security contracting and NGO health service provision during the global governance intervention in Afghanistan.

\section{Private Security Contractors in Afghanistan}

Performance arguments have played a central role in justifying the outsourcing of military and security ser- vices in global governance to private contractors (Krahmann, 2010; Stanger, 2009). This outsourcing has so far been the most pronounced during the intervention in Afghanistan. Between 2008 and 2012, the number of private security guards contracted with the US DoD increased more than tenfold from 2,745 to 28,686 (CENTCOM, 2014). Disconcertingly, about $90 \%$ of security contractors were armed (Schwartz, 2011, p. 2). The DoD has sought to legitimize the outsourcing of security by means of performance targets and measures. The US Army Handbook Developing a Performance Work Statement [PWS] in a Deployed Environment (US Army, 2009, p. 4; hereafter PWS Handbook) thus praises the benefits of performance measurements, arguing that they ensure that the 'government pays for results, not activity'.

However, the intervention in Afghanistan demonstrates that DoD contracts and assessments usually define security outcomes in terms of performative activities and capabilities. In the minds of contracting officials, these performative acts comply with the increased focus on intended results, not processes' because they are equated with outcomes (US Army, 2009, p. 9). Moreover, these performative acts can be assessed in terms of visible, quantifiable and attributable performance indicators. The PWS Handbook (US Army, 2009, p. 22), thus, instructs contracting units to develop performance tasks which meet the SMART test, i.e. they must be specific, measurable, attainable, relevant and timely. In addition, the PWS Handbook (US Army, 2009, p. 26) identifies five methods for monitoring: random sampling, periodic sampling, one hundred percent inspection, trend analysis, and customer feedback. Repetitive performative acts, capabilities or interventions fit all but the last of these methods.

That a performative definition of security is not merely a matter of convenience, but of conviction is illustrated by the way in which the DoD formulates performance tasks for security contractors in Afghanistan. The PWS for Private Security Services at Camp Bravo, Forward Operating Base Heredia in Afghanistan, for example, defines performance tasks either as actions, e.g. 'searching personnel and vehicles' and 'periodic checking of interior perimeter' or as capabilities and equipment, e.g. 'ammunition' and 'AK-47' (CENTCOM, 2012, p. 2). Similarly, the PWS for Counter-Narcoterrorism (CNT) states: 'The Contractor shall provide security and related services in support of CNT and CNT related missions to include, but not limited to, intelligence, medical, logistics, canine services, surveillance, counter surveillance, aerial over watch, security advisory etc'. (DoD, 2007, p. 19). Occasional references to the purpose of performative acts such as to 'deny the introduction of unauthorized weapons or contraband, to prevent theft of US Government Property and to ensure only authorized personnel gain access' imply that the specified tasks refer to results, even if these are not measured by performance assessments (CENTCOM, 2012, p. 2). The demand for a repetitive reenactment of these security activities and capabilities is 
another characteristic of DoD performance tasks which denotes their performative nature. A CENTCOM (2009) solicitation for 'Armed Security Guards/Private Security Providers' in Afghanistan thus requires that 'Contractor(s) must be available 24 hours a day, 7 days a week'.

US Army criteria for evaluating the performance of security contractors serve as further illustrations of the shift from performance outcomes to performative acts (Government Accountability Office [GAO], 2006, p. 25). These criteria measure performance in terms of: 1) activities, such as 'denying access', 'appropriate conduct', 'response to incidents of employee misconduct', 'working with the Army organization', 2) capabilities, such as 'required level of guard coverage' and 'ability to respond to duty changes', and 3) the characteristics of contractors, such as 'responsiveness, alertness, physical fitness, courtesy' and 'proper appearance' (GAO, 2006, p. 25). They refer to only a single result, namely that contractors should contribute to the 'positive image' of the armed forces. Yet, the formulation of these criteria and the use of verbs such as; 'achieve', 'maintain', 'manage' and 'control', suggests that they are believed to represent security outcomes (GAO, 2006, p. 25).

The implications of defining security in terms of performative acts are considerable. Firstly, this definition prevents a critical assessment of the socially constructed effects of performative security acts. Such an assessment includes, but should not be limited to, investigations of whether the activities and capabilities of private security contractors contribute to lowering probabilities of harm or increasing perceptions of security among mission personnel and the local Afghan population. It must be noted that how an audience interprets and reacts to performative acts depends on pre-existing socio-cultural ideas. Actions and contractor characteristics, which in some social situations and environments contribute to lower levels of harm or subjective feelings of security, can lead to increased violence or perceptions of insecurity in others.

Secondly, the definition of security in terms of specific, attainable, measurable, attributable and observable performative acts determines in a very particular way how PSCs have operated in Afghanistan. The Statement of Work for the private security contractor at Camp Bravo (CENTCOM, 2012), for example, stipulates exactly who should be employed ('indigenous personnel'), what kinds of weapons must be used ('M9, M4, M16, or equivalent'), what equipment the contractor must carry (e.g. 'protective body armor, helmets, uniforms, secure communications') and what activities they must carry out (e.g. 'Searching personnel and vehicles entering and leaving the installations', 'Manning Guard Towers, Checkpoints and other static positions 24 hours a day, 7-days a week', 'checking of the interior perimeter defenses'). DoD notions of suitable security performances, thus, shape which activities and capabilities are provided and which are excluded from contracts, performance measurements and implementation strategies, despite potentially beneficial effects for the security perceptions, risk levels and relationships of the mission and host societies.

\section{NGOs and Public Heath Care in Afghanistan}

Performance measurements have also become important for legitimizing the activities of NGOs in global governance, including the delivery of public health services (Fowler, 1996; Lynch-Cerullo \& Clooney, 2011; Spar \& Dail, 2002). When in 2002 the new Afghan Ministry of Public Health (MoPH) and major international donors, such as the European Union, USAID and the World Bank, decided to outsource essential health care to NGOs the World Bank emerged as a leading advocate of performance-based contracting to demonstrate effectiveness, ensure public accountability and obtain legitimacy (Sondorp et al., 2009, p. 141). The World Bank argued that performance rather than input-based contracting would give NGOs the 'freedom to reach their targets using creative solutions adapted to local situations while keeping efficiency and effectiveness in mind' (World Bank, 2013).

In practice, however, the World Bank's collaboration with NGOs has been characterized by a focus on performative acts. For example, the targets within the 'Basic Package of Health Services' (BPHS) set by the MoPH on the advice of the WHO adopted a performative definition of health which equated interventions with outcomes (MoPH, 2003, 2005). The observation that Afghanistan 'faced some of the worst health statistics ever recorded worldwide, including an infant mortality rate of 165 per 1,000 live births and 1,600 maternal deaths for every 100,000 live births' thus resulted in performance tasks defined by comprehensive list of services (MoPH, 2005, p. 1; see also Cashin et al., 2015, p. 9). Although the MoPH (2005, p. 4) asserted that the BPHS would consider the question 'Do the services proposed have an impact on the major health problems?' the contingent and variable relationship between the performance of health services and health outcomes was not reconsidered once these lists had been drawn up.

Since 2003, the World Bank has extended its performative conception of health to NGOs contracted to implement the BPHS in up to 31 out of 34 Afghan provinces. ${ }^{2}$ The 'Balanced Scorecard', developed by the World Bank in collaboration with the MoPH, Johns Hopkins University and the Indian Institute of Health Management Research, has assessed performance 'results' in terms of: (1) capabilities, e.g. facilities, number of female staff, equipment, availability of laboratory tests and drugs, (2) administration, e.g. record taking and training plans, and (3) interventions, e.g. number of household

\footnotetext{
${ }^{2}$ Due to the streamlining of funding for health care through the System Enhancement for Health Action in Transition program from 2013-2018, the performance-based contracting approach was expanded to include funds from other donors, who had previously managed their own contracts with NGOs. See http://www.worldbank.org/en/news/feature/2015/12/22/afghanistan-builds-capacity-meet-healthcare-challenges
} 
visits, consultations, vaccinations, and antenatal care (Cashin et al., 2015, Annex 1). NGOs have received additional 'results-based' payments if the aggregate number of health interventions exceeded those of the previous year by more than $10 \%$ (Cashin et al., 2015, p. 11). Public health outcomes, such as the services' impact on DALYs or subjective perceptions of health and health service quality, have not been monitored, despite extensive and costly verification measures which, amongst other performance criteria, cross-checked the number of reported interventions through household surveys (Cashin et al., 2015, p. 10).

As in the case of security, two main consequences have emerged from the performative approach to health care in Afghanistan. One has been a shift of focus away from public health outcomes. A national mortality survey carried out in $\mathbf{2 0 1 0}$ did indeed report improvements in public health indicators, including life expectancy, infant mortality and maternity deaths (MoPH, 2011). However, the performative approach to health adopted by the World Bank has precluded a critical assessment of the services supplied through the BPHS and their sociallymediated effects on these and other health outcomes. The observation that 'service utilization had plateaued and in some cases decreased in 2009', including vaccination rates, raises questions over whether the performative health services provided by NGOs in Afghanistan have met the socially constructed notions of suitable and relevant health interventions for the Afghan population (Cashin et al., 2015, p. 11).

The analysis further problematizes the dominant role played by international donors and organizations in the definition of 'appropriate' performative acts in the field of public health. Several NGOs, including Médecins Sans Frontières, Médecins du Monde and the International Committee of the Red Cross, decided to opt out of the bidding process for health service provision because they felt that the objectives adopted by the donors were 'contradictory to their neutrality and independence mandates' (Bousquet, 2005, p. 16). Although the Afghan $\mathrm{MoPH}$ agreed to and implemented the performative approach to health care, its policies were largely shaped by the interests and health care conceptions of international donors, organizations and consultants and not those of the Afghan population (MoPH, 2003, 2005).

\section{Conclusion}

Output legitimacy, derived from performance assessments and performance-based contracting, is an important standard for global governance. The outsourcing of global governance to private actors such as NGOs, PSCs and transnational corporations has drawn specifically on this strategy to gain legitimacy and public approval. However, in many cases, the attainment of publicly desired outcomes as a measure of performance has been replaced with a focus on performative acts, i.e. the specification and assessment of contractors' capabilities, char- acteristics and repetitive enactments of specific activities and interventions.

This article has sought to provide a theoretical explanation and an empirical illustration of the shift from performance to performativity through the examples of security and health care provision. It has been argued that the implications of this shift for the conceptualization, and implementation, of global governance interventions are considerable. As illustrated by the example of the global security and health governance interventions in Afghanistan, two consequences stand out. First, a performative definition of public services which equates performative acts with outcomes precludes a critical assessment of the actual effects of these interventions. Second, since international rather than local actors determine the definition of what constitutes 'suitable' performative acts, this conceptualization leads to a systematic disregard for the socially constructed nature of performative acts. Performative acts only 'work', i.e. achieve desired outcomes, if they conform to existing social expectations.

In conclusion, the preceding developments logically undermine the attempts to legitimize private actors in global governance through performance-based contracting and performance assessments because these measures neither examine outcomes nor consider their social desirability and acceptance. It follows that we need to look at performance assessments through new eyes, not only in security and health but also within other fields of global governance. Further research will be necessary to investigate the local and international consequences of this development for global security and health interventions in more detail and to establish whether and under what circumstances its findings also apply to other global governance actors and sectors.

\section{Acknowledgements}

The author would like to thank the organisers and participants of the conference 'The Legitimization of Private and Public-Private Regulation: Past and Present' held at the Max Planck Institute for European Legal History in Frankfurt as well as the anonymous reviewers for their comments and suggestions.

\section{Conflict of Interests}

The author declares no conflict of interests.

\section{References}

Baldwin, D. A. (1997). The concept of security. Review of International Studies, 23(1), 5-26.

Bialasiewicz, L., Campbell, D., Elden, S., Graham, S., Jeffrey, A., \& Williams, A. J. (2007). Performing security: The imaginative geographies of current US strategies. Political Geography, 26(4), 405-422.

Bousquet, C. (2005). Performance-based contracting for 
health service delivery in post-conflict Afghanistan: Is there still a case for debate? Paris: Group URD. Retrieved from www.urd.org/IMG/pdf/PPA_is_there_ still_case_for_debate.pdf

Brassett, J., \& Vaughan-Williams, N. (2015). Security and the performative politics of resilience: Critical infrastructure protection and humanitarian emergency preparedness. Security Dialogue, 46(1), 32-50.

Butler, J. (1988). Performative actors and gender constitution: An essay in phenomenology and feminist theory. Theatre Journal, 40(4), 519-531.

Butler, J. (1990). Gender trouble: Feminism and the subversion of identity. New York, NY: Routledge.

Cashin, C., Fleisher, L., \& Hashemi, T. (2015). Verification of performance in results-based financing (RBF): The case of Afghanistan. Washington, DC: World Bank.

CENTCOM. (2009). Armed security guards/private security provider, solicitation. Federal Business Opportunities. Retrieved from www.fbo.gov/index?s =opportunity $\&$ mode $=$ form $\&$ id $=623 e 06 f 2 f 116 f 482 f 9$ 48e758aef72ad5

CENTCOM. (2012). Private security contractor, Camp Bravo-FOB Heredia, statement of work. Federal Business Opportunities. Retrieved from www.fbo.gov /index?s=opportunity \&mode $=$ form \&id=8a79f17d1cf e0563a2da2c04b7092b9b\&tab=core\&_cview $=1$

CENTCOM. (2014). Quarterly contractor census reports. Office of the Assistant Secretary of Defense for Logistics \& Materiel Readiness. Retrieved from www.acq.osd.mil/log/PS/CENTCOM_reports.html

Department of Defense. (2007). Performance work statement (PWS) for DoD counter narcoterrorism technology office (CNTPO) program and operations support (SW-ZZ-09-06).

Fowler, A. (1996). Demonstrating NGO performance: Problems and possibilities. Development in Practice, 6(1), 58-65.

Glenn, J. (2008). Global governance and the democratic deficit: Stifling the voice of the south. Third World Quarterly, 29(2), 217-238.

Government Accountability Office. (2006). Contract security guards: Army's guard program requires greater oversight and reassessment of acquisitions approach (GAO-06-284). Washington, DC: Government ACcountability Office.

Higate, P., \& Henry, M. (2009). Insecure spaces: Peacekeeping, power and performance in Haiti, Kosovo and Liberia. London: Zedbooks.

Higate, P., \& Henry, M. (2010). Space, performance and everyday security in the peacekeeping context. International Peacekeeping, 17(1), 32-48.

Joachim, J., \& Schneiker, A. (2012). New humanitarians? Frame appropriation through private military and security companies. Millennium-Journal of International Studies, 40(2), 365-388.

Johnson, C., Dowd, T. J., \& Ridgeway, C. L. (2006). Legitimacy as social process. Annual Review of Sociology, $32,53-78$.
Krahmann, E. (2008). Security: Collective good or commodity? European Journal of International Relations, 14(3), 379-404.

Krahmann, E. (2010). States, citizens and the privatization of security. Cambridge: Cambridge University Press.

Krahmann, E. (2011). Beck and beyond: Selling security in the world risk society. Review of International Studies, 37(1), 349-372.

Lewis, J. (2015). The politics and consequences of performance measurement. Policy and Society, 34(1), 1-12.

Lister, S. (2003). NGO legitimacy: Technical issue or social construct? Critique of Anthropology, 23(2), 175-192.

Lynch-Cerullo, K., \& Clooney, K. (2011). Moving from outputs to outcomes: A review of the evolution of performance measurement in the human service nonprofit sector. Administration in Social Work, 35(4), 364-388.

Martin, L. L., \& Kettner, P. M. (1997). Performance measurement. Administration in Social Work, 21(1), 17-29.

Mathers, C. D., Salomon, J. A., Murray, C. J. L., \& Lopez, A. D. (2003). Alternative summary measures of average population health. In C. J. L. Murray \& D. B. Evans (Eds.), Health systems performance assessment: Debates, methods and empiricism (pp. 319334). Geneva: World Health Organization.

Ministry of Public Health. (2003). A basic package of health services for Afghanistan. Kabul: Ministry of Public Health.

Ministry of Public Health. (2005). A basic package of health services for Afghanistan, 2005/1384. Kabul: Ministry of Public Health.

Ministry of Public Health. (2011). Afghanistan mortality survey 2010. Kabul: Ministry of Public Health.

$\emptyset$ stensen, $\AA$. (2011). In from the cold? Self-legitimating the market for private security. Global Change, Peace \& Security, 23(3), 369-385.

Radin, B. A. (2007). Performance measurement and global governance: The experience of the World Bank. Global Governance, 13(1), 25-33.

Rothschild, E. (1995). What is security? Daedalus, 124(3), 53-98.

Salomon, J. A., Mathers, C. D., Chatterji, S., Sadana, R., Üstün, T. B., \& Murray, C. J. L. (2003). Quantifying individual levels of health: Definitions, concepts, and measurement issues. In C. J. L. Murray \& D. B. Evans (Eds.), Health systems performance assessment: Debates, methods and empiricism (pp. 301318). Geneva: World Health Organization.

Scharpf, F. W. (1998). Interdependence and democratic legitimation (MPIfG Working Paper 98/2). Cologne: Max Planck Institute.

Scharpf, F. W. (2009). Legitimacy in the multilevel European polity. European Political Science Review, 1(2), 173-204.

Schwartz, M. (2011). The Department of Defense's use of private security contractors in Iraq and Afghanistan: 
Background, analysis, and options for Congress. Washington, DC: Congressional Research Service.

Sondorp, E., Palmer, N., Strong, L., \& Wali, A. (2009). Afghanistan: Paying NGOs for performance in a postconflict setting. In R. Eichler \& R. Levine (Eds.), Performance incentives for global health: Potential and pitfalls (pp. 139-164). Washington, DC: Brookings Institution Press.

Spar, D., \& Dail, J. (2002). Of measurement and mission: Accounting for performance in non-governmental organizations. Chicago Journal of International Law, 3(1), 171-181.

Stanger, A. (2009). One nation under contract: The outsourcing of American power and the future of foreign policy. New Haven, CT: Yale University Press.

Suchman, M. C. (1995). Managing legitimacy: Strategic and institutional approaches. Academy of Management Review, 20(3), 571-610.

Take, I. (2012). Legitimacy in global governance: International, transnational and private institutions compared. Swiss Political Science Review, 18(2), 220-248.

US Army. (2009). Developing a performance work statement in a deployed environment (Handbook 09-48). Retrieved from http://usacac.army.mil/sites/ default/files/publications/09-48.pdf

Wallner, J. (2008). Legitimacy and public policy: Seeing beyond effectiveness, efficiency, and performance. The Policy Studies Journal, 36(3), 421-443.
Williams, A. J. (2011). Reconceptualising spaces of the air: Performing the multiple spatialities of UK military air spaces. Transactions of the Institute of British Geographers, 36(2), 253-267.

World Bank. (2002). Public health and World Bank operations. Washington, DC: World Bank. Retrieved from siteresources.worldbank.org/HEALTHNUTRITIONAND POPULATION/Resources/Peer-Reviewed-Publication s/PHOperations.pdf

World Bank. (2013). Afghanistan: Better health outcomes for women, children, and the poor. World Bank. Retrieved from www.worldbank.org/en/res ults/2013/04/18/afghanistan-better-health-outcomes -women-children-poor

World Health Organization. (2008). Performance measurement for health system improvement: Experiences, challenges and prospects. Geneva: World Health Organization. Retrieved from www.who.int/ management/district/performance/PerformanceMe asurementHealthSystemImprovement2.pdf

World Health Organization. (2016). Metrics: Disabilityadjusted life year (DALY). World Health Organization. Retrieved from www.who.int/healthinfo/global_ burden_disease/metrics_daly/en/

Zaiotti, R. (2011). Performing Schengen: Myths, rituals and the making of European territoriality beyond Europe. Review of International Studies, 37(2), 537-556.

\section{About the Author}

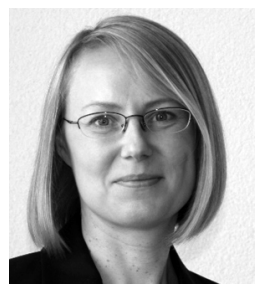

Elke Krahmann is Professor of International Political Studies at Witten/Herdecke University, Germany. She has published widely on non-state actors and global governance, including her Ernst-Otto Czempiel award-winning monograph States, Citizens and the Privatization of Security (Cambridge University Press, 2010). Her latest ESRC-funded research project has examined the use of private security contractors by international organisations such as the United Nations, NATO, and the European Union. 